\title{
Educational Philosophies of the Ancient Philosophers and Their Implications on the National Policy on Education of the Federal Republic of Nigeria
}

\author{
Dr. Caleb Danjuma Dami PhD*
}

Gindiri Theological Seminary (Affiliated to University of Jos) PMB 01001, Jos, Plateau State, Nigeria Research Associate, Stellenbosch University South Africa

DOI: $10.36348 /$ sb.2019.v05i12.015 $\quad$ | Received: 14.12.2019| Accepted: 22.12.2019| Published: 28.12.2019

*Corresponding author: Dr. Caleb Danjuma Dami PhD

\section{Abstract}

This article argues that the current National Policy on Education of the Federal Republic of Nigeria has its roots in the educational philosophies of the ancient philosophers. The article states, discusses and traces the three major ideas and the development of educational Philosophies of the ancient Philosophers, namely Socrates, Plato and Aristotle. The article further discusses how their ideas has shaped or influenced subsequent philosophers of Education as postulated by John Dewey, John Milton, Gregory and Abraham Maslow. In application the paper concludes by comparing and contrasting the National Policy on Education of the Federal Republic of Nigeria with the above schools of thought.

Keywords: Education, Ancient Philosophers, Nigeria, National Policy on Education, Socrates, Plato, Aristotle, Dewey, Gregory, Maslow.

Copyright @ 2019: This is an open-access article distributed under the terms of the Creative Commons Attribution license which permits unrestricted use, distribution, and reproduction in any medium for non-commercial use (NonCommercial, or CC-BY-NC) provided the original author and source are credited.

\section{INTRODUCTION}

This paper traces the development of educational philosophies of the ancient philosophers, namely, Socrates, Plato and Aristotle. This is done by stating and discussing three of their major ideas. Also, the paper further discusses how their ideas have shaped or influenced subsequent philosophies of education as postulated by John Dewey, John Milton Gregory and Abraham Maslow. In application, the paper compares and contrasts the educational policy of Federal Republic of Nigeria today with the above schools of thought.

\section{Major Philosophical and Educational Ideas from Socrates, Plato and Aristotle}

Socrates (c.470- 399B.C.) was born in Athens where he spent most of his life. He developed a teaching method that remains in use today. Some regard him as the most important figure in ancient education. Socrates was well-known for his unique method of instruction. He began his day walking through the school yard asking questions of his students. Socrates worded his questions such as to require students to analyze and synthesize before formulating a response [1]. Barefooted in Athens, he wandered among his students, ever questioning, ever insisting upon reason, and ever pressing the issues of the nature of man [2].

Socrates believed that the first task of a teacher was to awaken the student through self- examination and self- criticism. This in itself set Socrates apart from the Sophists, teachers of eloquence and rhetoric, who often claimed to know all. His aim in education was to expose error and, in so doing discover truth [3]. His role in teaching was to enable people to discover wisdom by themselves from within. To this end, he employed dialectic. His task was to assist at the birth of wisdom in his partners through dialogue. The wisdom itself came from heaven [4].

Socrates is generally regarded as primarily a teacher of ethics with no interest in abstract philosophy or any desire to found a new school of thought .... At any rate we can be reasonably sure that Socrates believed in a stable and universally valid knowledge, which man could possess if he would only pursue the right method [5]. Hardly a Christian in his understanding of God of creation, Socrates was nevertheless committed to a universe that reflected a moral order and a definite purpose. The agnosticism of 
the Sophists was blasphemy to him, for only the truly moral man could exhibit true knowledge [6]. Socrates was committed to a world generated by a moral order and a definite reason for existence. To Socrates, only the moral individual could possess true knowledge. Plato's Apology quotes Socrates as saying, "The unexamined life is not worth living [7]".

Plato (c. 427- 347 B.C.), Plato is probably the most significant philosopher of ancient Greece. Plato's notions regarding the nature of man is seen in the following prepositions:

i) Man is composed of two basic substances, matter and spirit (a body and a soul). ii) The superior substance is spiritual and immortal. iii) Evil tendencies in man are usually associated with matter. iv) Although there is universal and immutable human nature, important differences are found in men; these differences are rooted in the different levels of intelligence. v) Social classes are determined by levels of intelligence; the intellectual elite are charged with the function of governing the masses. vi) Man possesses a free will and is wholly responsible for his behavior. vii) Reason alone gives true knowledge, and sense knowledge is wholly unreliable [8].

Plato developed his celebrated doctrine of ideas. He admitted that relativity and constant change are characteristics of the world of physical things, of the world we perceive with our senses. But he denied that this world is the complete universe. There is a higher, spiritual realm composed of eternal forms of ideas which only the mind can conceive. These are not, however, mere abstractions invented by the mind of man, but spiritual things. The things we perceive with our senses are merely imperfect copies of the supreme realities, Ideas [9].

Plato was a thoroughgoing idealist with an extreme emphasis of mind and reason. His system of truth-searching centered on reason to the exclusion of revelation. Plato believed that men are bound to a false concept of reality and must therefore be converted or released from that bondage. The release involves turning one's love from the deceptive sphere of operation, in which sense data provides knowledge and principles for living, to the divine sphere of operation, in which innate knowledge and intellect give the true pictures of reality [10]. Anthony agrees when he also asserts that, "According to the father of idealism, human beings are restricted to the confines of their earthly cave, limited in what they have come to know as real based upon the five senses (i.e., sight, sound, smell, taste, and touch). But, according to Plato, these objects that we have come to experience are mere images." [11]. Francis A. Schaeffer agrees that, "In the school of Athens Raphael painted Plato with one finger pointed upward, which means that he pointed towards absolutes or ideals[12]."
Plato's philosophy of education is found in three of his dialogues: the Protagoras, Republic, and Laws. For Plato, education should unify the individual with society. He emphasized the need for interaction between body and mind as the basis for education. The four virtues (wisdom, temperance, courage, and justice) were the points of union between the individual and the society. According to Plato, the soul possesses three kinds of abilities: reason, spirit, and appetite. Reason enables humans to discern truth. Spirit translates wisdom into action. Appetite relates to bodily functions. His method of education was designed to instruct humans by leading their souls towards the four virtues.

Plato's philosophy cannot be understood apart from his interest in politics and the political situation in Greece at the time he lived. For Plato education was a means to an end, namely, social and political reform. An understanding of Plato's philosophy rests on a comprehension of his comparison of the individual with the state. For Plato, the state represented the highest interests of the individual. It would therefore establish educational standards and could use any means (even immoral ones) to indoctrinate its citizens [13]. Plato established a residential school on the outskirts of Athens around 385 B.C. known as the Academy, where he specialized in the subjects of mathematics and literature. Here he taught students for the service of the state for a period of forty years [14]. Another significant contribution of Plato's educational philosophy relates to his belief that women should be equal recipients of education along with men.

Aristotle and Realism. Just as Plato was the pupil of Socrates, Aristotle (384- 322 B.C.) was the pupil of Plato. There were some likenesses between teacher and student, but many more differences as Aristotle demonstrated early by his disavowal of Plato's idealism and his founding of what we have to call historic realism [15]. In contrast to Plato, "Rapheal pictured Aristotle with his fingers spread wide and thrust down toward the earth, which means that he emphasized particulars. By particulars we mean the individual things which are about us; a chair is a particular, as is each molecule which makes up the chair, and so on." [16]. Thomas Aquinas brought this Aristotelian emphasis on individual things - the particulars - into the philosophy of the late Middle Ages, and this set the stage for the humanist elements of the Renaissance and the basic problem they created. Aristotle was actively a great scientist.

Aristotle's criticism of Plato particularly rejected the concept that knowledge is a priori. He argued that there is no referenced knowledge outside of experience, and therefore rejected Plato's dislocation of "objects" from one world, putting them in another world where they could not be contemplated. Rather than thinking about things that the common person 
could not understand (as Plato argued philosopher-king should do). Aristotle countered that it should be the function of leaders in society to provide a straightforward description of the objects about them, hence the difference between classic idealism and classic realism [17].

Realism tends to reject idealistic dualism and argues that the universe is monistic, like a giant machine set up to run in accordance with certain inexorable laws. Truth becomes the discovery of those laws by objective observation, sampling, empirical description, and statistical analysis. One cannot thwart the natural laws, so society becomes a matter of setting up human organizations so they can best function in accordance with the absolute laws of the universe [18]. For Aristotle, society is a natural institution, and the state is the highest achievement of nature and humans. He viewed slavery as natural institution, since he believed nature makes one person superior to another [19]. Aristotle's philosophy was highly analytical and systematic. Aristotle's own philosophy was an attempt to formulate more satisfactory and systematic views of physical and metaphysical reality. Whereas the Academy stressed mathematics, the Lyceum laid emphasis on biology and scientific research [20].

Aristotle taught that the highest good for man consists in self-realization, that is, in the exercise of that part of man's nature which most truly distinguishes him as a human being. Self-realization would therefore be identical with the life of reason [21]. Education, according to Aristotle, involved a process of selfrealization for a person as a rational being. He discerned three developmental periods: one of primarily physical growth, then a period of the emergence of the irrational, and, finally, a period dominated by reason. The first period of formal education lasted from age seven until puberty. During these years the child would be trained in reading, writing, gymnastics, music, and drawing. What was learned was to be put immediately into practice, because it was for the enhancement of life, and not for the vocation. The second period of education was to last from puberty to age twenty-one. But, Aristotle did not decide this period upon Aristotle's own school, the Lyceum was devoted to the intellectual growth of young adults of the third period (eighteen to twenty) [22].

How Socrates, Plato and Aristotle's Ideas have shaped and influenced subsequent philosophies of education by John Dewey, John Milton and Abraham Maslow.

\section{John Dewey}

Pragmatism is America's contribution to the history of philosophical thought. It is associated with John Dewey (1859- 1952) among others. Pragmatism has intellectual antecedents in those Greek thinkers, who maintain that people can know only what their senses experience [23]. The pragmatists emphasized empirical science, the changing world and its problems, and nature as the all-inclusive reality beyond which their faith in science would not allow them go. From the pragmatists' perspective, humanity lives in what Plato described as the cave of sensory perception. This, they claim, may not be the sum total of reality; but; like it or not, the cave is all we have. We live in a world of experience and have no way of knowing whether what some people claim lies beyond human experience has any truth or reality [24]. Democracy, experimentalism, and instrumentalism are then seen as some of the major concepts and designation by which Dewey's educational philosophy is known. They are the ideal values that lie at the heart of Dewey's mature philosophy and unifying moral faith [25]. Dewey viewed the school as a miniature community or embryonic society, in effect, a democracy, a school is the indispensible laboratory, and the testing ground, for both society and the building of a philosophy of education. In the school both individual and social problems are solved.

The important thing about students, from the pragmatists' epistemological viewpoint, is that they have experiences. They are experiencing individuals who are capable of using their intelligence to resolve problematic situations. For the pragmatist, the school experience is a part of life, rather than a preparation for life [26]. Traditional educational philosophies put subject matter at the center of the educational focus. The child was supposed to conform to the demands of the structure of the several curricular areas. Pragmatism rejected that approach and placed students and their needs and interests on center stage. Subject matter, it claimed, should be chosen with an eye to the needs of the student. The curriculum, according to Dewey and other pragmatists, should not be divided into restrictive and unnatural subject-matter areas. It should rather be built around natural units that grow out of the pressing questions and experiences of the learner [27].

Dewey held that all study, at the outset should fall within the scope of ordinary life-experience. In other words, the child, according to him, should gradually move from learning based upon direct experiences to vicarious learning methods. These vicarious methods should then be all the more meaningful, since they are built upon a knowledge base founded upon significant experiences in everyday life [28].

Dewey clearly follows after Aristotle in his teaching that education has to do with the senses, there is nothing that can be known outside the senses. All knowledge is within that realm. What you experience is the reality not the form as Plato saw it. 


\section{John Milton Gregory}

John Milton Gregory defines education when he states, "Let us, like the Master, carefully observe a little child, that we may learn from him what education is; for education, in its broadest meaning, embraces all the steps and processes by which an infant is gradually transformed into a full-grown and intelligent man" [29]. For Gregory, on these two facts rest the two notions of education: (1) the development of capacities, and (2) the acquisition of experience. The first is the maturing of body and mind to full growth and strength; the second is the process of furnishing the child with the heritage of the race [30].

Based upon these two forms of educational science, we find the art of education to be a two-fold one: the art of training and the art of teaching. Since the child is immature in the use of all his capacities, it is the first business of education to give such training that will bring them to full development. This training may be physical, mental, or moral.

Since the child is ignorant, it is the business of education to communicate to it the experience of the race. This is properly the work of teaching. Considered in this light, the school is but one of the agencies of education, since we continue throughout our lives to acquire experience. The first object of teaching, then, is to stimulate in the pupil the love of learning, and to form in him habits and ideals of independent study. For Gregory, these two, the cultivation of capacities and the transmission of experience, together make up the teacher's work.

That aim is stated in its title - The Seven Laws of Teaching. Its object is to set forth, in a certain systematic order, the principles of the art of teaching. It deals with mental capacities only as they need to be considered in a clear discussion of the work of acquiring experience in the process of education. The seven laws are as follows:

- A teacher must be one who knows the lesson or truth or art to be taught.

- A learner is one who attends with interest to the lesson.

- $\quad$ The language used as a medium between teacher and learner must be common to both.

- $\quad$ The lesson to be mastered must be explicable in the terms of truth already known by the learner the unknown must be explained by means of the known.

- $\quad$ Teaching is arousing and using the pupil's mind to grasp the desired thought or to master the desired art.

- $\quad$ Learning is thinking into one's own understanding a new idea or truth or working into habit a new art or skill.

- $\quad$ The test and proof of teaching done - the finishing and fastening process - must be a reviewing, rethinking, reknowing, reproducing, and applying of the material that has been taught, the knowledge and ideals and arts that have been communicated [31].

The great aims of education as far as Gregory is concerned are to acquire knowledge and ideals, and to develop abilities and skills [32].

\begin{abstract}
Abraham Maslow (1908- 1970)
Maslow believed that too much psychological study had emphasized research on animals and the mentally impaired. Instead, he chose to focus his research on those who were mentally healthy (selfactualized). He believed that children make wise choices for their own learning when given the opportunity. Teachers arrange attractive and meaningful learning situations, and students select from those they find personally valuable. In this climate, teacherdirected classroom management becomes secondary to the motivating power of self-chosen activities [33]. Maslow develops this in what is popularly called Abraham Maslow's hierarchy of needs. This approach identifies five major groupings of needs. The needs are physical, safety, social, ego, and self-actualization. This theory holds that the most basic unmet need is motivator. Once the need is satisfied, that need no longer motivates. Then the next higher level becomes the motivator. Motives usually move upward unless a lower level need occurs again. Ideally, persons move up the hierarchy. In actuality some people never get to the highest level of self-actualization [34].
\end{abstract}

Level one: Physiological needs. These are most basic human needs. If a person has food, then food is no longer a need. MEs have few leaders or workers whose physiological needs are unmet.

Level two: Safety needs. Maslow identifies the safety needs as security, stability, dependency, protection, freedom from fear, freedom from anxiety and chaos, need for structure, order, law, limits, and strength in the protector, to name a few.

Level three: belonging and love needs. These needs are felt by the person who recently moved to town or to a new church and is hungry for caring relationships. Such persons need to be a part of a family or a group. They strive with great intensity to satisfy this need. They accept places of leadership to feel they belong. They try to avoid feeling the pangs of loneliness, of ostracism, of rejection, of friendlessness, or rootlessness.

Level four: Esteem needs. Maslow states, “All people... have a need or desire for a stable, firmly based, unusually high evaluation of themselves, for self-respect, or self-esteem, and for the esteem of others. These needs subdivide into two sets. The first 
set is the desires for strength, achievement, adequacy, mastery and competence, confidence, and independence and freedom. The second set is the desires for reputation or prestige (respect or esteem from other people), status, fame and glory, dominance, recognition, attention, importance, dignity, or appreciation. When the self-esteem needs are satisfied, feelings of selfconfidence, worth, strength, capability, and adequacy emerge. When these needs are thwarted, feelings of inferiority, weakness, and helplessness result.

Level Five. Need for self-actualization. When the previous levels of needs are met, people often feel a new discontentment and restlessness. These develop because they are not doing what they are fitted to do. What people can be, they must be. They must be true to their nature for this is the only way they are "selfactualized." Self- actualized persons have certain qualities. They see reality clearly. They can accept themselves at all levels - love, safety, belongingness, honor, self-respect. They are spontaneous in behavior. Individual differences are greatest at this level. For them, motivation is character growth, character expression, maturation, and development. They feel they have some mission in life, some task to fulfill. This task is one they feel is their duty or obligation. They are concerned with basic issue and eternal questions. Maslow says, "Self-actualizing people have the capacity to appreciate again and again, freshly and naively, the basic goods of life, with awe, pleasure, wonder, and even ecstasy [35].

\section{Comparing and Contrasting the Educational Policy} of Nigeria Today with the above Schools of Thought In Nigeria's philosophy of Education, it is believed that:

(a) Education is an instrument for national development; to this end, the formulation of ideas, their integration for national development and the interaction of the persons and ideas are all aspects of education [36]. This position is affirmed in the introduction to the National Policy on Education, where it states, "Education in Nigeria is an instrument 'per excellence' for effecting development." [37]. Nigeria's policy of education is similar to Plato's as stated that "Plato's motive for directing his investigation had a practical outcome because he sought to preserve and strengthen the beloved city of his birth. For Aristotle, however, the end result of his inquiry did not have to have practical application. Inquiry served its own purpose without having to possess utility. He was not a reformer of politics, education, or society as a whole; he advocated the acquisition of knowledge for its own sake." [38]. For Plato education was a means to an end, namely, social and political reform [39]. This is clearly reflected in Nigeria's Policy on Education that "the five main national goals of Nigeria, which have been endorsed as the necessary foundation for the National Policy on Education, are the building of: (a) a free and democratic society; (b) a just and egalitarian society; (c) a great and dynamic economy; (d) a land full of bright opportunities for all citizens.

(b)Education fosters the worth and development of the individual, for each individual's sake, and for the general development of the society [40]. This philosophy indicates Plato's views related to education as follows: (a) the tripartite nature of the state is similar to that of the persons (rational, emotional, and desiring), and the purpose of education is to equip persons to function as citizens in one of three classes (philosophers, warriors, laborers) that are manifestations of this nature. (b) Education was integral to developing the ideal state as outlined in the Republic. (c) The goal of education was to bring the potential of the person to be manifested in outward life, morally and socially [41].

(c) Plato's division of education into three stages of primary, secondary and higher education corresponds to general Western practice today. This shaped and also influenced Nigeria's Policy on Education. Sections 4, 5, and 8 reflect these three stages of education, primary, secondary and tertiary. Pragmatism placed students and their needs and interests on the center stage. Subject matter, it claimed, should be chosen with an eye to the needs of the student. The curriculum, according to Dewey and other pragmatists, should not be divided into restrictive and unnatural subject-matter areas. It should rather be built around natural units that grow out of the pressing questions and experiences of the learner. The Nigeria philosophy of Education states:

(d) There is need for functional education for the promotion of a progressive, united Nigeria; to this end, school programmes need to be relevant, practical and comprehensive; while interest and the ability should determine the individual's direction in education [42].

Aristotle's submission is also captured here; it should be practical and relevant. Not just ideas, but should involve our senses. Also, Gregory's two facts on the two notions of education: (1) the development of capacities, and (2) the acquisition of experience are reflected. The first is the maturing of body and mind to full growth and strength; the second is the process of furnishing the child with the heritage of the race featured in Nigeria's Policy on Education.

\section{CONCLUSION}

Socrates was committed to a world generated by a moral order and a definite reason for existence. To Socrates, only the moral individual could possess true knowledge. Socrates believed that the first task of a teacher was to awaken the student through selfexamination and self- criticism. Socrates worded his questions such as to require students to analyze and 
synthesize before formulating a response. Plato was a thoroughgoing idealist with an extreme emphasis on mind and reason. His system of truth-searching centered on reason to the exclusion of revelation. For Plato education was a means to an end, namely, social and political reform. Aristotle's philosophy was highly analytical and systematic. Aristotle's own philosophy was an attempt to formulate more satisfactory and systematic views of physical and metaphysical reality. While Socrates centered on moralism, Plato was on idealism and Aristotle was on realism. These philosophies have shaped greatly the views of John Dewey, John Milton Gregory and Abraham Maslow; and have also greatly influenced the National Policy on Education of the Federal Republic of Nigeria.

\section{REFERENCE}

1. Anthony, Michael, J., \& Benson, Warren, S. (2011). Exploring the History and Philosophy of Christian Education: Principles for the $21^{\text {st }}$ Century. Eugene, Oregon: Wipf \& Stock, 58.

2. Gangel, Kenneth, O., \& Benson, Warren, S. (2002). Christian Education: Its History and Philosophy. Eugene, Oregon: Wipf \& Stock, 35.

3. Reed, James, E., \& Prevost. (1993). Ronnie. A History of Christian Education. Nashville: Broadman\& Holman Publishers, 30.

4. Brown, Colin. (1990). Christianity and Western Thought: A History of Philosophies, Ideas and Movements. From the Ancient World to the Age of Enlightenment Volume One. Illinois: IVP Academic, 28.

5. Burns, Edward, McNall. (1968). Western Civilizations: Their History and Their Cultures, Vols. I\&II, $8^{\text {th }}$ Edition. New York: W. W. Norton \& Company, 135.

6. Gangel, Kenneth, O., \& Benson, Warren, S. (2002). Christian Education: Its History and Philosophy. Eugene, Oregon: Wipf \& Stock, 36.

7. Anthony, Michael, J., \& Benson, Warren, S. (2011). Exploring the History and Philosophy of Christian Education: Principles for the $21^{\text {st }}$ Century. Eugene, Oregon: Wipf \& Stock, 59.

8. Anthony, Michael, J., \& Benson, Warren, S. (2011). Exploring the History and Philosophy of Christian Education: Principles for the $21^{\text {st }}$ Century. Eugene, Oregon: Wipf \& Stock, 59.

9. Burns, Edward, McNall. (1968). Western Civilizations: Their History and Their Cultures, Vols. I\&II, $8^{\text {th }}$ Edition. New York: W. W. Norton \& Company, 135-136.

10. Gangel, Kenneth, O., \& Benson, Warren, S. (2002). Christian Education: Its History and Philosophy. Eugene, Oregon: Wipf \& Stock, 41.

11. Anthony, Michael, J., \& Benson, Warren, S. (2011). Exploring the History and Philosophy of Christian Education: Principles for the $21{ }^{\text {st }}$ Century. Eugene, Oregon: Wipf \& Stock, 61.
12. Schaeffer, Francis, A. (1976). How Should We Know Live? The Rise and Decline of Western Thought and Culture. New Jersey: Fleming H. Revell Company, 52.

13. Gangel, Kenneth, O., \& Benson, Warren, S. (2002). Christian Education: Its History and Philosophy. Eugene, Oregon: Wipf \& Stock, 39.

14. Anthony, Michael, J., \& Benson, Warren, S. (2011). Exploring the History and Philosophy of Christian Education: Principles for the $21^{\text {st }}$ Century. Eugene, Oregon: Wipf \& Stock, 55.

15. Gangel, Kenneth, O., \& Benson, Warren, S. (2002). Christian Education: Its History and Philosophy. Eugene, Oregon: Wipf \& Stock, 45.

16. Schaeffer, Francis, A. (1976). How Should We Know Live? The Rise and Decline of Western Thought and Culture. New Jersey: Fleming H. Revell Company, 52.

17. Gangel, Kenneth, O., \& Benson, Warren, S. (2002). Christian Education: Its History and Philosophy. Eugene, Oregon: Wipf \& Stock, 45

18. Gangel, Kenneth, O., \& Benson, Warren, S. (2002). Christian Education: Its History and Philosophy. Eugene, Oregon: Wipf \& Stock, 45.

19. Reed, James, E., \& Prevost, (1993). Ronnie. A History of Christian Education.Nashville: Broadman\& Holman Publishers, 31.

20. Brown, Colin. (1990). Christianity and Western Thought: A History of Philosophies, Ideas and Movements. From the Ancient World to the Age of Enlightenment Volume One. Illinois: IVP Academic, 40

21. Burns, Edward, McNall. (1968). Western Civilizations: Their History and Their Cultures, Vols. I\&II, $8^{\text {th }}$ Edition. New York: W. W. Norton \& Company, 138.

22. Reed, James, E., \& Prevost. (1993). Ronnie. A History of Christian Education. Nashville: Broadman\& Holman Publishers, 32.

23. Knight, George, R. (2006). Philosophy and Education: An Introduction in Christian Perspectives. Michigan: Andrews University Press, 67.

24. Knight, George, R. (2006). Philosophy and Education: An Introduction in Christian Perspectives. Michigan: Andrews University Press, 67.

25. Anthony, Michael, J., \& Benson, Warren, S. (2011). Exploring the History and Philosophy of Christian Education: Principles for the $21^{\text {st }}$ Century. Eugene, Oregon: Wipf \& Stock, 29.

26. Knight, George, R. (2006). Philosophy and Education: An Introduction in Christian Perspectives. Michigan: Andrews University Press, 72.

27. Knight, George, R. (2006). Philosophy and Education: An Introduction in Christian Perspectives. Michigan: Andrews University Press, 72. 
28. Knight, George, R. (2006). Philosophy and Education: An Introduction in Christian Perspectives. Michigan: Andrews University Press, 73.

29. Gregory, John, M. (1995). The Seven Laws of Teaching Michigan: Baker Books, 18.

30. Gregory, John, M. (1995). The Seven Laws of Teaching Michigan: Baker Books 19.

31. Gregory, John, M. (1995). The Seven Laws of Teaching Michigan: Baker Books 19.

32. Gregory, John, M. (1995). The Seven Laws of Teaching Michigan: Baker Books, 88.

33. Anthony, Michael, J., \& Benson, Warren, S. (2011). Exploring the History and Philosophy of Christian Education: Principles for the $21^{\text {st }}$ Century. Eugene, Oregon: Wipf \& Stock, 107.

34. Stubblefield, Jerry, M. (1993). The Effective Minister of Education: A Comprehensive Handbook. Tennessee: Broadman\& Holman Publishers, 176.

35. Stubblefield, Jerry, M. (1993). The Effective Minister of Education: A Comprehensive
Handbook. Tennessee: Broadman\& Holman Publishers, 178.

36. Federal Republic of Nigeria. National Policy on Education. $4^{\text {th }}$ Edition. (2004). Section 1: Philosophy and Goals of Education in Nigeria, 1.

37. Federal Republic of Nigeria. National Policy on Education. $4^{\text {th }}$ Edition, (2004) ii.

38. Anthony, Michael, J., \& Benson, Warren, S. (2011). Exploring the History and Philosophy of Christian Education: Principles for the $21^{\text {st }}$ Century. Eugene, Oregon: Wipf \& Stock, 66.

39. Gangel, Kenneth, O., \& Benson, Warren, S. (2002). Christian Education: Its History and Philosophy. Eugene, Oregon: Wipf \& Stock, 39.

40. Federal Republic of Nigeria. National Policy on Education. $4^{\text {th }}$ Edition. (2004).Section 1: Philosophy and Goals of Education in Nigeria, 1.

41. Reed, James, E., \& Prevost. (1993). Ronnie. A History of Christian Education.Nashville: Broadman \& Holman Publishers, 30.

42. Federal Republic of Nigeria. National Policy on Education. $4^{\text {th }}$ Edition. (2004).Section 1: Philosophy and Goals of Education in Nigeria, 1. 